\title{
Coping Strategies of Economically (Partially) Inactive Households: The Case of Croatia
}

Bagić, Dragan; Dobrotić, Ivana; Lažnjak, Jasminka; Rodik, Petra; Vučković Juroš, Tanja

Source / Izvornik: Südosteuropa, 2017, 65, 542 - 564

Journal article, Published version

Rad u časopisu, Objavljena verzija rada (izdavačev PDF)

https://doi.org/10.1515/soeu-2017-0034

Permanent link / Trajna poveznica: https://urn.nsk.hr/urn:nbn:hr:131:979445

Rights / Prava: In copyright/Zaštićeno autorskim pravom.

Download date / Datum preuzimanja: 2023-04-26

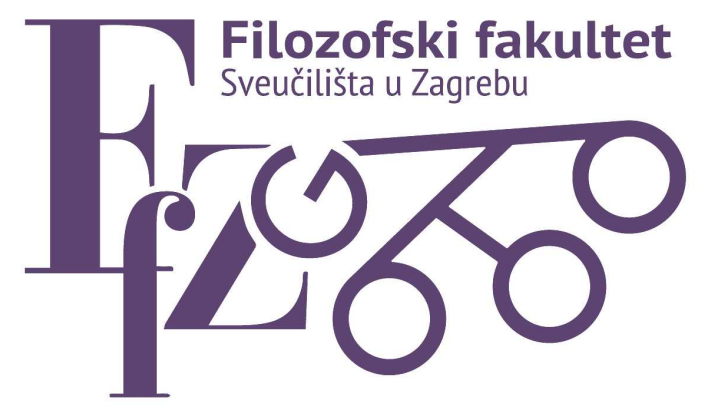

Repository / Repozitorij:

ODRAZ - open repository of the University of Zagreb

Faculty of Humanities and Social Sciences
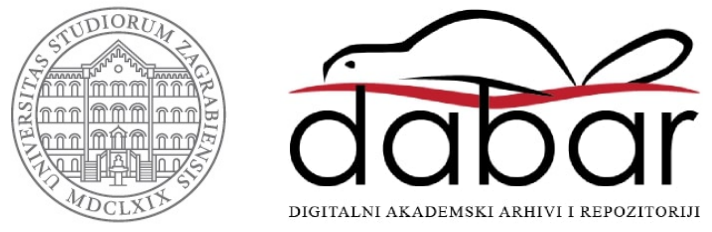


\title{
DRAGAN BAGIĆ, IVANA DOBROTIĆ, JASMINKA LAŽNJAK, PETRA RODIK, and TANJA VUČKOVIĆ JUROŠ
}

\section{Coping Strategies of Economically (Partially) Inactive Households: The Case of Croatia}

\begin{abstract}
How do households with inactive or unemployed members face growing risks and uncertainty? The present study tackles this problem with a case study on Croatia, a country at the bottom of the European Union's (EU) scale of economic activity rate. The low level of activity that has characterized Croatia for more than twenty years has been accompanied by a continuously high unemployment rate, which has further increased since 2009. In this context, households with (long-term) inactive or unemployed members have had to develop alternative coping strategies. In order to identify and examine these strategies, in 2014 we conducted a mixed-method study, including a quantitative survey of 453 households and 37 semi-structured interviews. We identified six household strategies, more or less 'successful' in terms of the household's material position. In this essay we further examine these strategies' characteristics and implications, with a focus on the profiles of households employing specific strategies.
\end{abstract}

Dragan Bagić is an Assistant Professor in the Department of Sociology at the University of Zagreb.

Ivana Dobrotić is an Assistant Professor in the Department of Social Policy at the University of Zagreb.

Jasminka Lažnjak is a Professor in the Department of Sociology at the University of Zagreb. Petra Rodik is an Assistant Professor in the Department of Sociology at the University of Zagreb.

Tanja Vučković Juroš is a Postdoctoral Researcher in the Department of Social Policy at the University of Zagreb.

\section{Introduction}

How do households with (long-term) inactive or unemployed members cope in vulnerable economies? The present study examines this problem with a case study on Croatia, a country whose current score of $61.4 \%$ puts it at the bottom of the European Union's (EU) scale of economic activity rate. Although Croatia's activity rate has further dropped during the recent global economic crisis, this 
trend is not new. A relatively low rate of economic activity has characterized the Croatian economy for more than twenty years. ${ }^{1}$ Surprisingly, this trend has not increased measured poverty, as one might expect in a country where long-lasting low participation in the formal labour market is coupled with high unemployment rates. ${ }^{2}$ In this paper, we examine what lies behind this puzzle.

The recent crisis has brought about a deterioration in labour market conditions in Croatia. While rises in unemployment, poverty, and inequality have been experienced across the EU, and the chances of entering the labour market have consequently decreased across the board, ${ }^{3}$ Croatia stands out as the country with the strongest cumulative fall in economic activity and the strongest scale of employment destruction. ${ }^{4}$ The Croatian recession was prolonged, and the positive economic trends, which started as late as 2015, were unable to counteract the recession's negative consequences. ${ }^{5}$ The labour market was already showing a remarkable loss of jobs. The low employment rate of $64.9 \%$ in 2008 further declined to $57.2 \%$ in $2013,{ }^{6}$ the year in which Croatia joined the EU. The crisis negatively affected the employment dynamics, leading to successive annual drops in employment, and changed the structure of new employment, increasing hiring based on temporary contracts. ${ }^{7}$ Croatia's unemployment and long-term unemployment rates, respectively $17.2 \%$ and $11 \%$ in 2013 , are among the highest in the EU. ${ }^{8}$ This particularly affects young people, the elderly, and the low-skilled, all of whom are particularly vulnerable when entering the labour market and at greater risk of being laid off during a crisis. ${ }^{9}$ With the prolonged crisis as a push factor and access to the EU labour market as a pull factor, emigration rates from Croatia intensified, with the crude rate of net migration reaching -4.3 per 1,000 inhabitants in $2015 .{ }^{10}$ These developments, along with the rise in public debt (rise from 50.3\% of the GDP in 2006 to $82.2 \%$

${ }^{1}$ Eurostat, Labour Market Database, http://ec.europa.eu/eurostat/data/database. All internet references were accessed on 28 April 2017.

2 Zoran Šućur, Stagnira li doista siromaštvo u Hrvatskoj?, Društvena istraživanja 21, no. 3 (October 2012), 607-629, DOI:10.5559/di.21.3.01.

${ }^{3}$ European Commission, Employment and Social Developments in Europe 2014, 26 April 2017, http://ec.europa.eu/social/main.jsp?catId=89\&langId=en\&newsId=2172\&furthe rNews=yes.

${ }^{4}$ Mislav Brkić, Labour Market Duality and the Impact of Prolonged Recession on Employment in Croatia, Croatian Economic Survey 17, no. 1 (June 2015), 5-45, DOI:10.15179/ces.17.1.1.

5 Croatian Chamber of Economy, 27 April 2017, http://www.hgk.hr/documents/aktualna-tema-rast-bdp-a58beced171c45.pdf.

${ }^{6}$ Eurostat, Labour Market Database.

7 Brkić, Labour Market Duality.

8 Eurostat, Labour Market Database.

9 Teo Matković, Tko što radi? Dob i rod kao odrednice položaja na tržištu rada u Hrvatskoj, Revija za socijalnu politiku 15, no. 3 (2008), 479-502, DOI: 10.3935/rsp.v15i3.802.

10 Eurostat, Crude Rate of Net Migration Plus Adjustment, 28 April 2017, http://ec.europa. $\mathrm{eu} /$ eurostat $/ \mathrm{tgm} / \mathrm{table} . \mathrm{do} ? \mathrm{tab}=$ table\&init $=1 \&$ plugin $=1 \&$ code $=$ tsdde230\&language $=$ en . 
in 2013) and the corresponding increased deficit (rise from -3.0\% of GDP in 2006 to $-5.3 \%$ in 2013), ${ }^{11}$ resulted in Croatia being placed under the EU's excessive deficit procedure, which is an additional obstacle to growth and reforms and contributes to further welfare state retrenchment.

Individuals were forced increasingly to rely on their own resources for survival and to face the risk of insecure and fragmented life trajectories due to long-term unemployment, long periods of working for no pay, indebtedness, and so forth. ${ }^{12}$ In these circumstances, how did economically (partially) inactive households cope without succumbing to poverty? We explore this question through the concept of 'household strategies'. We argue that this criticized concept is relevant in postcommunist and postfordist societies, societies of growing risk and uncertainty in which individuals must draw on various resources. The concept's analytical strength most notably stems from its ability to capture both formal and informal and domestic resources that are used and combined within a particular household. It thus provides a better understanding of economic behaviour in a given context. ${ }^{13}$ Household strategies develop at the intersections of the labour market, the welfare system, and personal networks ${ }^{14}$ but they are also influenced by other factors, such as household market or culture. ${ }^{15}$

Previous research in Croatia has examined some aspects of household strategies, particularly how they are influenced by the labour market-specifically, the grey market, the welfare system, or networks of formal and informal support ${ }^{16}$ - but we are aware of no existing study that has focused specifically on

11 Eurostat, Economy and Finance Database, 28 April 2017, http://ec.europa.eu/eurostat/ data/database.

12 Matković, Tko što radi?; Ivan Burić, Nacija zaduženih. Od komunističkog pakla do potrošačkog kapitalizma, Zagreb 2010; Petra Rodik / Mislav Žitko, Financialization, Household Debt and New Vulnerabilities in Post-Socialist Societies, in: Dubravko Radošević / Vladimir Cvijanović, eds, Financialization in Eastern Europe, Frankfurt/M. 2015, 49-70; Ivana Dobrotić, Crisis and Croatian Welfare State. A New Opportunity for Welfare State Retrenchment, in: Klaus Schubert / Paloma de Villota / Johanna Kuhlmann, eds, Challenges to European Welfare Systems, New York 2016, 301-324.

13 Claire Wallace, Household Strategies. Their Conceptual Relevance and Analytical Scope in Social Research, Sociology 36, no. 2 (May 2002), 275-292, DOI: 10.1177/0038038502036002003.

14 Claudia Gardberg Morner, Making Ends Meet. Lone Mothers' Local Subsistence Strategies. Case Studies from Italy and Sweden, Mannheimer Zentrum für Europäische Sozialforschung Working Papers 13, Mannheim 2000, http://www.mzes.uni-mannheim.de/publications/ wp/wp-13.pdf.

15 Wallace, Household Strategies.

${ }^{16}$ Nenad Karajić, Siromaštvo i neslužbeno gospodarstvo u Hrvatskoj- kvalitativni aspekti, Financijska teorija i praksa 26, no. 1 (2002), 273-299, http://hrcak.srce.hr/5938; Vlado Puljiz et al., eds, Socijalna politika Hrvatske, Zagreb 2008; Ivana Dobrotić / Maja Laklija, Obrasci društvenosti i percepcija izvora neformalne socijalne podrške u Hrvatskoj, Društvena istraživanja 21, no. 1 (January 2012), 39-58, DOI:10.5559/di.21.1.03; Tihana Rubić, Nezaposlenost i neformalna ekonomija u Hrvatskoj: analiza diskursa, Studia ethnologica Croatica 25 (2013), 61-92, http:// hrcak.srce.hr/ojs/index.php/sec/article/view/2370. 
the strategies of (partially) inactive households. We use the data collected in the 2014 mixed-methods project 'Typology of Survival Strategies and Sources of Income of Economically (partially) Inactive Households', which combined results from a survey of households with unemployed or inactive members with the information obtained from semi-structured interviews conducted on a purposive subsample of such households. ${ }^{17}$

In the next section, we present the conceptualization of 'household strategies'. We then detail the research design and methods. Following that, we present the six household strategies identified in the Croatian households with unemployed or inactive members. In the final section, we discuss our main findings and implications for further research and policymaking.

\section{Household Strategies: Conceptualization and Issues}

'Strategy' has become a widely used concept in sociology as the focus has moved away from the structural approach towards social actors. The growing popularity of 'strategy' as a social theory concept is partially a response to 'hard structuralism', ${ }^{18}$ and it also provides a chance to move beyond the structure/ agency dichotomy. The concept of 'household strategies' was first used in household studies in Latin America and Africa in the 1980 s. ${ }^{19}$ It was then adopted by the socio-economic paradigms research in the late industrial and post-industrial era in Western countries. These later studies focused on structural changes in working families dealing with, for instance, the consequences of women's entrance into the labour market. ${ }^{20}$ The concept was initially applied to specific and marginal social groups who had to make a greater effort to survive (e.g. farmers, small business entrepreneurs, and immigrants), but it was later used for all households. ${ }^{21}$ These studies found differences in strategies or ways of coping between working rich and working poor households. ${ }^{22}$ Unlike previous

17 The project was funded under the programme contracts of the University of Zagreb. The Research Ethics Committee, Department of Sociology, Faculty of Humanities and Social Sciences, Zagreb, has issued an approval of compliance of procedures applied in this research with ethical standards.

18 Graham Crow, The Use of the Concept of 'Strategy' in Recent Sociological Literature, Sociology 23, no. 1 (February 1989), 1-24, 1, http://www.jstor.org/stable/42854579.

${ }_{19}$ Wallace, Household Strategies.

20 Phyllis Moen / Elaine Wethington, The Concept of Family Adaptive Strategies, Annual Review of Sociology 18 (August 1992), 233-251, DOI: 10.1146/annurev.so.18.080192.001313.

21 Wallace, Household Strategies; Kavita Datta et al., From Coping Strategies to Tactics. London's Low-Pay Economy and Migrant Labour, British Journal of Industrial Relations 45, no. 2 (June 2007), 404-432, DOI: 10.1111/j.1467-8543.2007.00620.x.

22 R.E. Pahl, Some Remarks on Informal Work, Social Polarization and the Social Structure, International Journal of Urban and Regional Research 12, no. 2 (June 1988), 247-267, DOI: 10.1111/ 
deterministic structural approaches to class/stratification analyses, findings of the household strategies studies highlighted individual action, agency, and its rationality. ${ }^{23}$

Both Wallace and Crow approach these issues from the bottom up and from a micro-sociological perspective. They define household strategy as 'a concept that takes into account the motivations and agency of actors in society' ${ }^{24}$ dealing with what course of action a household decides to follow. It is an inductive concept grounded in empirical research, in which households are asked how they are coping with the consequences of recession, decreasing salaries, and problems paying bills and housing loans. ${ }^{25}$ Although there is no consensus about the concept's definition, its theoretical usefulness stems from capturing actions that are rational and take place in predictable social situations, which indicates the existence of a choice between alternatives. ${ }^{26}$ Warde $^{27}$ distinguishes between weak and strong strategies, where strong strategies refer to actual planning of activities, and weak strategies to activities that are not necessary planned but can be realised from the income available. However, in an approach critical of the 'household strategy' concept, Clark, in his analysis of Russian households in the transition period, argues that we can hardly talk about household strategies in circumstances where the household budget barely meets the basic needs of the household members and in which there is no space for strategic decision-making processes. ${ }^{28}$

Nevertheless, another strength of the 'household strategy' concept is that it reintroduces households as units of analysis into sociological analysis. It draws particular attention to various sources of income, in addition to regular income in the formal economy. ${ }^{29}$ By stressing the significance of informal or shadow and social economy for household sustainability, this opens up new directions in the empirical research on diversity of household subsistence. For

\footnotetext{
j.1468-2427.1988.tb00452.x.

${ }^{23}$ Wallace, Household Strategies.

${ }^{24}$ Wallace, Household Strategies, 275; Crow, The Use of the Concept of 'Strategy' in Recent Sociological Literature.

${ }^{25}$ We intentionally use the term 'housing loans' instead of mortgages because housing loans are secured by various other instruments (guarantors, insurance policies, etc.) on top of the mortgage.

${ }^{26}$ Crow, The Use of the Concept of 'Strategy' in Recent Sociological Literature.

27 Alan Warde, Household Work Strategies and Forms of Labour. Conceptual and Empirical Issues, Work, Employment and Society 4, no. 4 (December 1990), 495-515, DOI: 10.1177 /0950017090004004002.

28 Simon Clark, Making Ends Meet in Contemporary Russia. Secondary Employment, Subsidiary Agriculture and Social Networks, Cheltenham 2002.

${ }^{29}$ Enzo Mignione, Life Strategies and Social Economies in the Postfordist Age, International Journal of Urban and Regional Research 18, no. 1 (March 1994), 24-45, DOI: 10.1111/j.14682427.1994.tb00249.x.
} 
example, analyses of transition economies have used models such as 'multiple economies' to describe various informal and formal economic practices, such as paid work, informal work paid in cash, unpaid domestic labour, different kinds of assistance in labour, and cash assistance from family, friends, and neighbours. ${ }^{30}$ Smith and Stenning further distinguish between three categories of such practices: 1 ) market economic practices (formal and informal work and remittance economies); 2) non-market economic practices (e.g. domestic food production and self-provisioning, reciprocity, and the 'economy of regard', state benefits, and care work); and 3) alternative economic practices in the black and 'grey' economies. ${ }^{31}$

Several empirical studies have highlighted the diversity of practices and resources the households use in difficult circumstances. According to Clark, Russian households depend on traditional resources such as income from primary and secondary employment, social benefits, and private transfers, but rural households also utilize produce from their garden plots. His analysis emphasizes that individuals do not plan strategies to maximize household income but rather combine different practices at hand to get by. ${ }^{32}$ Another interesting example of practices used in Russian households is that of co-residing with parents, relatives, and other adults, utilized by single mothers in a study by Lokshin and Yemtsov. ${ }^{33}$ These authors have used the concept of 'human capital' as the main criterion in their identification of Russian households' strategies. They have shown that households with higher levels of human capital are more likely to choose active strategies, while households with less human capital (e.g. those of retired and lower educated individuals) are more likely to suffer social exclusion. ${ }^{34}$ Next, a 2002 Serbian study of household strategies underscored the shift from passive and defensive to more active, work oriented strategies, which is a result of the labour market becoming perceived as an important instrument for improving one's socio-economic position. In fact, this study identified five types of strategic orientations aimed at improving one's social position: 1) work-related strategies; 2) strategies of capital accumulation

30 Marianna Pavlovskaya, Other Transitions. Multiple Economies of Moscow Households in the 1990s, Annals of the Association of American Geographers 94, no. 2 (June 2004), 329-351, DOI: 10.1111/j.1467-8306.2004.09402011.x.

31 Adrian Smith / Alison Stenning, Beyond Household Economies. Articulations and Spaces of Economic Practice in Postsocialism, Progress in Human Geography 30, no. 2 (April 2006), 190-213, DOI: 10.1191/0309132506ph601oa.

32 Clark, Making Ends Meet in Contemporary Russia.

${ }^{33}$ Michael Lokshin / Kathleen Mullan Harris / Barry M. Popkin, Single Mothers in Russia. Household Strategies for Coping with Poverty, World Development 28, no. 12 (December 2000), 2183-2198, DOI: https://doi.org/10.1016/S0305-750X(00)00070-X.

${ }^{34}$ Michael Lokshin/Ruslan Yemtsov, Households Strategies of Coping with Shocks in Post-Crisis Russia, Review of Development Economics 8, no. 1 (February 2004), 15-32, DOI: 10.1111/j.1467-9361.2004.00217.x. 
(cultural or financial); 3) exit strategies (e.g. emigration); 4) passive optimistic strategies (general reforms, followed by rise of living standards, are expected to improve one's social position); and 5) passive infirmity strategies (lack of belief in the possibility of improving one's position). ${ }^{35}$ Finally, a recent Serbian study proposed another interesting typology of life strategies based on two axial factors: individualism/collectivism and reactivity/proactivity. ${ }^{36}$

Unlike studies in postcommunist/transition countries, Western analyses of coping strategies focused more on specific social groups, such as foreign migrants, single mothers, or the long-term unemployed. ${ }^{37}$ Drawing mostly on surveys and in-depth interviews, these studies identify coping strategies in terms of support networks ${ }^{38}$ or reciprocity networks, ${ }^{39}$ social networks, supplementary employment, and public or private social services. ${ }^{40}$

We argue that 'household strategy' is a useful concept and method of analysis, particularly in postcommunist societies, which have been faced with various risks and uncertainties and in which (welfare state) reforms have responded inadequately to these risks. This has led households to draw on different resources, such as informal and domestic resources, in order to cope. These practices are context-dependent and often guided by informal rules not easily explained by conventional methods of analysis. But using the 'household strategies' concept brings them into focus and may indeed prove a more fruitful approach. ${ }^{41}$ Still, because the concept lacks conceptual clarity, we make use also of the accumulated knowledge on various informal and formal economic practices, and consider the particularities of the Croatian context, particularly over-in-

35 Marija Babović / Slobodan Cvejić, Starategija opstanka domaćinstava u Srbiji, Sociologija 44, no. 2 (2002), 97-126, http://www.doiserbia.nb.rs/img/doi/0038-0318/2002/003803180202097B.pdf.

36 Predrag Cvetičanin / Ivana Spasić / Danijela Gavrilović, Strategies and Tactics in Social Space. The Case of Serbia, Social Science Information 53, no. 2 (2014), 213-239, DOI: 10.1177/0539018413517182.

37 Datta et al., From Coping Strategies to Tactics; Alberta Andreotti, Coping Strategies in a Wealthy City of Northern Italy, International Journal of Urban and Regional Research 30, no. 2 (2006), 328-345, DOI: 10.1111/j.1468-2427.2006.00669.x; Gardberg Morner, Making Ends Meet. Lone Mothers' Local Subsistence Strategies.

38 Julia R. Henly / Sandra K. Danziger / Shira Offer, The Contribution of Social Support to the Material Well-Being of Low-Income Families, Journal of Marriage and Family 67, no. 1 (2005), 122-140, DOI: 10.1111/j.0022-2445.2005.00010.x.

39 Mignione, Life Strategies and Social Economies in Postfordist Age.

40 Julia Hastings / Sarah Taylor / Michael J. Austin, The Status of Low-Income Families in the Post Welfare Reform Environment. Mapping the Relationship between Poverty and Family, Journal of Health \& Social Policy 21, no. 1 (2005), 33-63, DOI: http://dx.doi.org/10.1300/ J045v21n01_02.

41 Wallace, Household Strategies. 
debtedness. ${ }^{42}$ Therefore, we used seven hypothetical strategies centred around income sources or cost-reduction strategies to operationalize indicators in this research: 1) reduction of needs and expenses; 2 ) low monetization (producing own food, firewood, exchange of goods and services, etc.); 3 ) income without work (e.g. income from property); 4) income from informal work (undeclared work); 5) reliance on social transfers; 6) intra-family solidarity; and 7) financial management (e.g. 'living on credit'). These initial strategies had a purely heuristic role in the operationalization of the research instruments.

\section{Research Design and Methods}

We conducted a mixed-method study, consisting of a quantitative household survey and qualitative semi-structured interviews. The survey was conducted on a national random representative sample of 1,000 households as part of the Ipsos Omnibus survey in early 2014. A two-step stratified multi-cluster sample was used. The sample was stratified by region and settlement size. Its structure is in line with the structure of population with respect to gender, age, educational level, and employment status of the respondent, who was randomly selected in the household through the weighting procedure using the Random Iterative Method. Our research targeted the households in which some of the working-age members were unemployed or inactive in the labour market. Based on the characteristics of all household members, a target group of 453 households (unweighted count) was identified out of the total of 1,000 households encompassed by the survey. These 453 households were included in the further analysis.

Questions for our research were included at the beginning and end of the questionnaire, which also contained blocks of questions on other topics. We collected data on the household structure, formal and informal sources of income, production of food for own consumption, income from property, income from social transfers, costs and housing cost savings, and the level of short-term household debt. Data were collected from a randomly selected household member, who was free to consult with other household members.

Based on these data, we created eleven variables (Table 1) and performed a cluster analysis in order to identify homogeneous strategies with regard to the combination of income sources and/or cost-reduction strategies of households with some economically inactive or (long-term) unemployed members. We used the K-means method of identifying homogeneous groups of households in the

${ }^{42}$ Burić, Nacija zaduženih; Rodik / Žitko, Financialization, Household Debt and New Vulnerabilities in Post-Socialist Societies; Petra Rodik, The Impact of the Swiss Franc Loans Crisis on Croatian Households, in: Serdar M. Değirmencioğlu / Carl Walker, eds, Social and Psychological Dimensions of Personal Debt and the Debt Industry, London 2015, 61-83. 
Table 1. Description of indicators of income sources and/or reduction of household costs.

\begin{tabular}{|c|c|c|}
\hline Name & Description & Values \\
\hline $\begin{array}{l}\text { Income from } \\
\text { agriculture }\end{array}$ & $\begin{array}{l}\text { Income from agriculture and food } \\
\text { produced for own consumption }\end{array}$ & $\begin{array}{l}0 \text { - No income or food production } \\
1 \text { - Some food produced for own } \\
\text { consumption } \\
2 \text { - Most of the food produced for own } \\
\text { consumption } \\
3 \text { - Most of the food produced for own } \\
\text { consumption and income from sell- } \\
\text { ing agricultural products }\end{array}$ \\
\hline $\begin{array}{l}\text { Income from } \\
\text { rent }\end{array}$ & $\begin{array}{l}\text { Income from renting apartments, sum- } \\
\text { mer houses, land, etc. }\end{array}$ & $\begin{array}{l}0 \text { - No income from rent } \\
1 \text { - Some income from rent } \\
2 \text { - Significant income from rent }\end{array}$ \\
\hline $\begin{array}{l}\text { Regular } \\
\text { income }\end{array}$ & $\begin{array}{l}\text { Proportion of income from permanent } \\
\text { (formal) employment and pension in } \\
\text { total income }\end{array}$ & \multirow{4}{*}{$\begin{array}{l}0-\text { No income } \\
1-\text { Up to } 20 \% \text { of total income } \\
2-20-50 \% \text { of total income } \\
3 \text { - More than } 50 \% \text { of total income }\end{array}$} \\
\hline $\begin{array}{l}\text { Occasional } \\
\text { work }\end{array}$ & $\begin{array}{l}\text { Share of income earned from unregu- } \\
\text { lated (undeclared) or occasional work } \\
\text { (contract or occasional jobs) }\end{array}$ & \\
\hline $\begin{array}{l}\text { Income } \\
\text { from social } \\
\text { transfers }\end{array}$ & $\begin{array}{l}\text { Income from social transfers such } \\
\text { as: alimony, child allowance, social } \\
\text { assistance, unemployment benefits, } \\
\text { financial assistance from local commu- } \\
\text { nity, etc. }\end{array}$ & \\
\hline $\begin{array}{l}\text { Help from } \\
\text { family mem- } \\
\text { bers }\end{array}$ & $\begin{array}{l}\text { Receiving money from family mem- } \\
\text { bers who do not live in the same } \\
\text { household }\end{array}$ & \\
\hline $\begin{array}{l}\text { Extraordi- } \\
\text { nary income }\end{array}$ & $\begin{array}{l}\text { Did the household in the twelve } \\
\text { months before the survey gain any sig- } \\
\text { nificant one-off extraordinary income, } \\
\text { such as gains from games of chance, } \\
\text { sports betting, severance pay in case of } \\
\text { retirement or redundancy, etc. }\end{array}$ & \multirow[t]{3}{*}{$\begin{array}{l}0-\text { No } \\
1-\text { Yes }\end{array}$} \\
\hline Savings & $\begin{array}{l}\text { In the past twelve months, was the } \\
\text { household forced to reach for savings } \\
\text { to settle regular costs of living }\end{array}$ & \\
\hline Property sale & $\begin{array}{l}\text { Has the household earned any income } \\
\text { from the sale of immovable property } \\
\text { in the past five years or from the sale } \\
\text { of movable property in the past twelve } \\
\text { months? }\end{array}$ & \\
\hline $\begin{array}{l}\text { Consumer } \\
\text { debt }\end{array}$ & $\begin{array}{l}\text { Share of short-term consumer debts } \\
\text { (consumer loans, credit cards, over- } \\
\text { draft) in total monthly household } \\
\text { income }\end{array}$ & $\begin{array}{l}0 \text { - No short-term debts } \\
1 \text { - Small short-term debts (up to 20\%) } \\
2 \text { - Significant short-term debts (20- } \\
50 \% \text { ) } \\
\text { 3- Large short-term debts (more than } \\
50 \% \text { ) }\end{array}$ \\
\hline $\begin{array}{l}\text { Housing } \\
\text { costs reduc- } \\
\text { tion }\end{array}$ & $\begin{array}{l}\text { Possibility of reducing some housing } \\
\text { costs }\end{array}$ & $\begin{array}{l}0 \text { - Pays all housing costs (rent/ } \\
\text { mortgage, utilities, etc.) } \\
1 \text { - Pays rent but does not pay some } \\
\text { utilities } \\
2 \text { - Does not pay rent but pays all } \\
\text { utilities } \\
3 \text { - Does not pay rent and does not pay } \\
\text { some utilities }\end{array}$ \\
\hline
\end{tabular}


IBM SPSS 17.0 software package. In order to select the optimal number of homogeneous household groups, we tested several solutions in regard to the number of output groups, which were determined a priori. The goal was to obtain as many homogeneous groups of households as possible whose profile differed on as many input variables as possible and whose profiles were interpretable. After testing solutions with four, five, six, seven, and eight output groups, we selected the solution with six groups as the one that best meets the set criteria.

Thirty-seven semi-structured interviews were conducted in early 2014 on the purposive sample of households that fitted two criteria: 1) they consisted of at least one inactive or unemployed working-age person; and 2) they relied on at least one of the seven hypothetical strategies centred on income sources or cost-reduction strategies listed in the previous section. For the latter criterion, the initial screening was performed by trained interviewers using a checklist listing sources of income and expenses. We sought to recruit respondents from different regions of Croatia, from both urban and rural settlements and of varied wealth, in order to achieve within-sample variability, although this was not maximum variation sampling in a strict sense..$^{43}$

At the beginning of the interview, every interviewee completed the same questionnaire used in the household survey. In the interview, they were asked to expand on their responses and more thoroughly explain the structure and the history of their income-producing practices and expenses. In addition, the interviewees were asked to talk about their satisfaction and future plans, the self-evaluation and background of their family situation, expense-reducing practices, and reliance on unpaid housework and care. All interviews were audio recorded and transcribed verbatim. The transcripts were anonymized, and in this paper we use only the pseudonyms of the research participants.

The three team members coded the data in Atlas.ti 7 software using the thematic coding approach. ${ }^{44}$ Coding was approached in an abductive manner, combining a pre-created coding scheme with the inductive formation of codes. Each coder first independently coded a subset of interviews, after which the codes were further discussed and refined by all three coders. After the second round of coding, a further check of intercoder reliability, and the preliminary analysis, the revised codes were grouped into categories of household descriptions.

43 Matthew B. Miles / A. Michael Huberman / Johnny Saldaña, eds, Qualitative Data Analysis. A Methods Sourcebook. Third Edition, Thousand Oaks/CA 2013; Charles Teddlie / Fen Yu, Mixed Methods Sampling. A Typology with Examples, Journal of Mixed Methods Research 1, no. 1 (January 2007), 77-100, DOI: 10.1177/2345678906292430.

44 Robert M. Emerson / Rachel I. Fretz / Linda L. Shaw, eds, Writing Ethnographic Fieldnotes, Chicago/IL 1995; Carl F. Auerbach / Louise B. Silverstein, eds, Qualitative Data. An Introduction to Coding and Analysis, New York 2003; Johnny Saldaña, ed, The Coding Manual for Qualitative Researchers, Los Angeles 2009. 
In the next stage of analysis, we compared the data from the household survey and the interviews. This comparison revealed a consistency between quantitative household clusters and qualitative household categories, so a coder further linked each interview with the best corresponding household cluster. This classification was double-checked by a second coder, and the differences resolved by discussion. After this procedure, thirty-five interviews were classified as belonging to one of the clusters; two were labelled 'untypical'. The comparison also resulted in a minor redefinition of variables in the cluster analysis, which led to the final cluster solution. The structure of the final cluster solution was very similar to the first one but allowed a somewhat clearer and more meaningful interpretation.

\section{Results: Six Household Strategies}

In this section we present the results of the survey of 453 Croatian households with unemployed or inactive working-age members combined with the results of semi-structured interviews on the purposive sample of thirty-seven households. Since the clusters identified in the household survey data correspond closely to the household categories identified in the interview data, the presentation of each household cluster and its strategies is followed by an in-depth presentation of the interview case we consider representative of that group.

The cluster analysis of the household survey data identified six types of households, which were statistically significantly different on eight out of eleven output variables: regular income, occasional work, income from agriculture, income from social transfers, help from family members, savings, consumer debt, and housing costs reduction. On the remaining three variables (income from rental property, income from property sale, and gains from extraordinary income), no statistically significant differences were found (Table 2).

\section{Household Strategy One: Struggle for Independence}

Households classified into cluster one predominantly rely on income from occasional work, help from family members living elsewhere, regular income, and savings. Their housing costs are high as they are dominantly flat-dwellers. A third of these households is mortgaged. They are primarily located in large and medium-sized cities and have little income from agriculture. Households from cluster one are the smallest of all types of households. They are dominated by younger and middle-aged people. They are primarily one-person households, although couples without children or with one child are over-represented as well. On average, one household member of working age is unemployed or inactive. Finally, compared to other households in the sample, according to 
Table 2. Final cluster centres and F-test.

\begin{tabular}{|l|c|c|c|c|c|c|c|c|c|}
\hline & Total & \multicolumn{7}{|c|}{ Final Cluster Centres } & \multicolumn{2}{c|}{ F-test } \\
\cline { 3 - 10 } & & 1 & 2 & 3 & 4 & 5 & 6 & $\begin{array}{c}F- \\
\text { value }\end{array}$ & Sig. \\
\hline Regular income & 2.26 & 0.73 & 2.89 & 2.84 & 0.06 & 2.97 & 0.18 & 638.14 & 0.000 \\
\hline Occasional work & 0.28 & 1.09 & 0.24 & 0.15 & 0.29 & 0.28 & 0.31 & 11.52 & 0.000 \\
\hline $\begin{array}{l}\text { Income from } \\
\text { agriculture }\end{array}$ & 0.84 & 0.05 & 0.50 & 1.77 & 0.56 & 0.26 & 0.76 & 79.06 & 0.000 \\
\hline Income from rent & 0.03 & 0.00 & 0.01 & 0.03 & 0.00 & 0.07 & 0.00 & 1.56 & 0.170 \\
\hline Property sale & 0.13 & 0.25 & 0.18 & 0.10 & 0.12 & 0.10 & 0.19 & 1.44 & 0.208 \\
\hline $\begin{array}{l}\text { Extraordinary } \\
\text { income }\end{array}$ & 0.04 & 0.11 & 0.00 & 0.03 & 0.06 & 0.06 & 0.03 & 1.57 & 0.167 \\
\hline $\begin{array}{l}\text { Income from } \\
\text { social transfers }\end{array}$ & 0.81 & 0.57 & 2.07 & 0.32 & 2.94 & 0.29 & 0.24 & 249.18 & 0.000 \\
\hline $\begin{array}{l}\text { Help from family } \\
\text { members }\end{array}$ & 0.13 & 0.64 & 0.07 & 0.03 & 0.35 & 0.08 & 0.25 & 10.42 & 0.000 \\
\hline Savings & 0.17 & 0.23 & 0.23 & 0.09 & 0.13 & 0.25 & 0.16 & 2.88 & 0.014 \\
\hline Consumer debt & 0.69 & 0.54 & 0.61 & 0.48 & 0.26 & 1.29 & 0.24 & 14.38 & 0.000 \\
\hline $\begin{array}{l}\text { Housing costs } \\
\text { reduction }\end{array}$ & 1.83 & 0.19 & 1.82 & 2.26 & 2.09 & 1.42 & 2.29 & 38.20 & 0.000 \\
\hline
\end{tabular}

their material deprivation index ${ }^{45}$ score they are slightly worse off than average (Table 3). ${ }^{46}$

This profile fits about $6 \%$ of the target population, and it is mostly shared by the corresponding interview household category. The latter particularly highlights how households of this type extensively rely on the support of their family, so we have labelled their strategy a Struggle for Independence. Matea's story (Case Summary 1), ${ }^{47}$ described below, provides one such case.

45 The material deprivation index was constructed on the model of the material deprivation rate used in the EU statistics on income and living conditions, see http://ec.europa. eu/eurostat/statistics-explained/index.php/Glossary:Material_deprivation. This rate reflects how many of the nine selected items of material standard the household cannot afford due to financial constraints. A higher score indicates greater material deprivation. Unlike the original material deprivation index with nine indicators, this study used an index with eight indicators, leaving out a washing machine.

${ }^{46}$ In light of limited space and the focus of the present paper, we have decided not to include the regional differences in our presentation and discussion of clusters' profiles. Regional differences are relevant as they have implications on the availability of certain types of incomes and cost-reducing strategies, but as this topic requires a more extensive presentation than is possible in this paper, we leave it for a separate paper.

47 We illustrate each strategy with a typical case, drawn from the interviews. The case summaries are in our wording, while interviewee's quotes are marked by single quotation marks and assigned a number designating their paragraph placement in the interview transcript. 


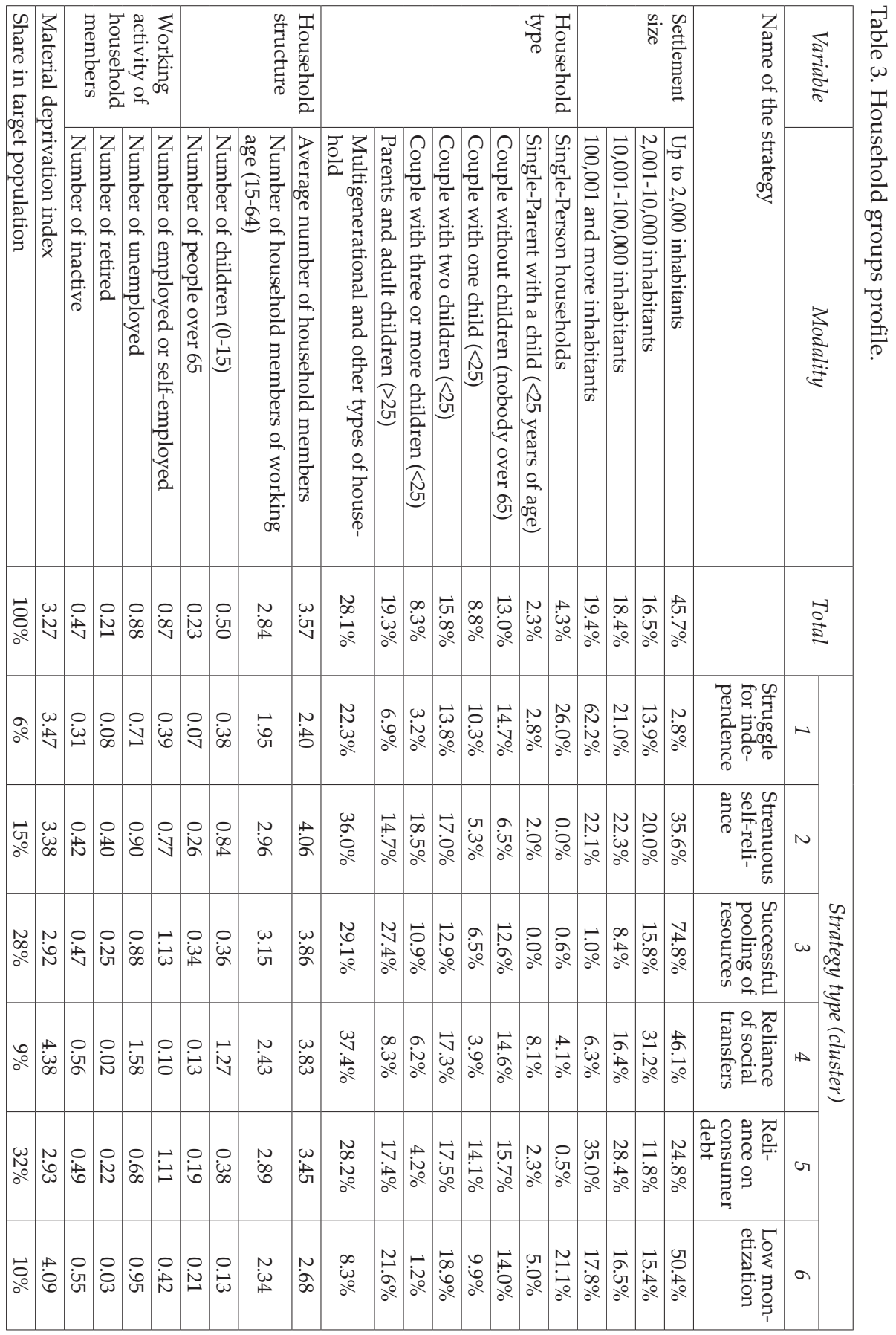


Case Summary 1. Struggle for Independence.

Matea, in her mid-twenties, lives in a [capital city] in a flat owned by her mother, who lives in another flat she owns. Matea finished secondary school and has never found a permanent job. Her mother pays all her housing expenses, and Matea's main income, which she mostly spends on food, going out, etc., comes from freelance jobs. Matea has a boyfriend living in a nearby town and he participates in joint expenses. He decides most things about their common budget, as he contributes much more to it. But 'when it comes to my own income and expenses, I consult with no one' (§76). She is not unsatisfied with her finances, but aspires for better. In the near future, she intends to move in with her boyfriend and rent the apartment where she lives now, which will give her additional income.

This case somewhat departs from the ideal type for cluster one due to Matea's low housing costs. Nevertheless, had she not been living in a rent-free flat, she would have had high housing costs, as living in a flat in the capital would require her to either pay rent or take out a housing loan.

\section{Household Strategy Two: Strenuous Self-Reliance}

Households classified into cluster two predominantly rely on regular income (formal work or pensions) and social transfers. They are located in settlements of various sizes but are below average in rural settlements of up to 2,000 inhabitants. They are also below average in their reliance on income from agriculture and help from family members living in other households. These are mostly large households, multigenerational families, and couples with three or more children. On average, they have at least one child below the age of 15 . Typically, they consist of three working-age members, with 1.3 individuals unemployed or inactive and an above-average share of individuals receiving regular income from pension. According to their material deprivation index, they are also slightly worse off than the sample's average (Table 3).

Based on the household survey and the interview data, we labelled the household strategy of this type, which characterizes around 15\% of our sample, a Strenuous Self-Reliance. It is illustrated by Barbara's story (Case Summary 2).

Case Summary 2. Strenuous Self-Reliance.

Barbara and her husband, both in their forties, live in a smaller coastal town, in a house, owned by her mother. They have two children-a daughter who studies in the capital and a son who has just started at university. Barbara's husband has secure full-time employment in public service, while she is unemployed and receives a disability allowance, which covers all her medical expenses. Their daughter receives a good scholarship and works part-time jobs during summer breaks, and her income covers $80-90 \%$ of her expenses. They do not receive any financial help from family members except occasional pocket money from grandmother to children. They have rent-free housing and pay only utilities, but several years ago they 
took out a loan for house renovation which they are still repaying. Their overall budget covers regular expenses and they have a savings accounts for the children. Nevertheless, any additional expenses (e.g. wedding presents, travel) are a source of financial distress and quarrels. They do not plan their budget much ahead, and Barbara tries not to think about the finances as her husband has 'the final word, he pays the bills [...]. What needs to be paid, needs to be paid (laughter) and that's it. Short and simple. I give him the bills and [...] he pays' $(\S 183,187)$. Her husband works the olive grove they co-own with Barbara's family, and they use some products from that labour for their own needs and the heating. They also grow some vegetables for their own needs, which reduces some of their living expenses. Barbara recognizes there are people who are worse off but she is still unsatisfied with their financial situation, which she does not expect to change any time soon: 'But, I have a feeling that I'll keep waiting to [...] never to catch, I have a feeling I'll never catch a break' (\$45).

\section{Household Strategy Three: Successful Pooling of Resources}

Households classified into cluster three predominantly rely on income from agriculture (mostly home-grown food), low/no housing costs (with some households even making savings on some utility bills), and regular income. The majority are located in rural settlements of up to 2,000 inhabitants. They are below average in their reliance on social transfers, help from family members living in other households, savings, and occasional work. On average, these households have 3.9 members, with over-representation of parents living with adult children over 25 . Presence of children below 15 is rarer than in other types of households, but there is higher than average presence of members over 65 . Typically, 1.3 household member is unemployed or inactive, and 1.13 member is employed. Households from cluster three, together with households from cluster five, are the least materially deprived households in our sample.

We labelled this household strategy a Successful Pooling of Resources. Cluster three accounts for $28 \%$ of households from the target population. It is illustrated by Iva's story (Case Summary 3).

\section{Case Summary 3. Successful Pooling of Resources.}

Iva lives in a three-generational household with six members: herself and her husband in their late forties, her husband's parents over 70, and two children, a son just under 20 and a daughter in her early twenties. The daughter, who is still perceived as a household member, studies in a coastal city where she lives with her husband, but Iva's household supports them financially. They live in a family house and rely on the combination of regular income and agricultural production, the latter used both for their own needs and for sale on the green market. Grandfather receives a pension, while grandmother has none. Iva's husband and son are both employed by the same factory. Iva lost her job in manufacturing, where she had spent most of her working life, five years ago. As she needs only a year and a half to fulfil the 
length of service requirement for a full pension, Iva aspires to find regular employment. Meanwhile, she accepts temporary unskilled jobs lasting 'maximum a month, or two weeks' (\$24). Iva explains that, for their household, the homegrown food is 'very important; we would have to spend very much if we had to buy all that we produce' (§97). Their relationship with friends and neighbours includes mutual inkind help with agricultural production, repairs, etc., which lowers their monetary expenses even further. On top of that, they prepare their own wood for heating, and Iva sews some of their clothing, which further reduces their needs for spending. They have small savings, 'just in case' (§63), and their overall budget covers day-to-day expenses but becomes tight in the case of unexpected expenses (e.g. major home appliance repairs/purchases). Iva points out that their living standard is fine compared to others. Nevertheless, she worries about the long-term future as their household budget is reliant on the pooling of multigenerational resources and the business success of one factory: 'I think this situation is not sustainable in the long-term. My son has a fixed-term contract, so there is a possibility that they don't extend it [...]. I often think about how we would live if my husband didn't work; if we did not have grandfather's pension, I really don't know how we would manage' (§ 45).

\section{Household Strategy Four: Reliance on Social Transfers}

Households in cluster four rely primarily on social transfers. They are further buffered by low housing costs. They are also above average in their reliance on help from family members not living in the same household. This type of household has no regular income and is characterized by little reliance on agricultural production and consumer debt. Typically, they live in smaller settlements (small towns or larger rural settlements). Similar to cluster three, these are relatively large households with, on average, 3.8 members, often multigenerational and consisting of parents with children. In fact, they stand out from other types of households with the number of children under 15, which make up a third of all members of these households. As many as 2.1 people of working age in these households are unemployed or inactive in the labour market, so they essentially have no formally employed members. As a result, they are the most materially deprived households of all households in our sample (Table 3).

Based on the household survey and interview data, we describe these households' strategy as Reliance on Social Transfers. This type of household accounts for about 9\% of the target population. Marko's story (Case Summary 4) represents one case that fits this strategy.

Case Summary 4. Reliance on Social Transfers.

Marko is a fifty-year-old man with secondary four-year vocational education who has had physical disability since his early childhood. He lives with his brother in his brother's flat in the capital and receives additional financial help from other family members. He used to live in a neighbouring ex-Yugoslav country, where 
he still owns a house (from which he receives no income) built on the land inherited from his father, but he moved to the Croatian capital after his divorce and the failure of his small business, which left him with debt he still repays. Marko's physical condition varies. He has periods when he is able to work but can hardly sustain physical work. Occasionally, he takes part-time manual jobs but he has depended on his family's financial support for over a decade now. After his last permanent job loss a few years ago, he developed mental health issues, too. He receives a monthly disability allowance, half of which is spent on medical bills. In the near future, he expects he will receive a disability pension, which will be only marginally higher than his current disability allowance. It will not allow him to support himself or move out of his brother's place. Marko feels himself to be a burden on his family, and his standard of living is very low. He sharply reduced all of his expenses: 'Simply, I don't drink, don't smoke, don't go out. It is like that. [...] I don't pay utility bills [...], since I moved to my brother's place I don't pay a thing' (\$§ 224-227). When asked if he feels in control of his financial situation, he says that he is very often worried about his health prospects, which also leads to financial concerns. He looks forward to getting that pension and repaying what is left of his debts. He feels that he has no control over his financial situation, and that 'only the family keeps me going. With the welfare you cannot live, there is no person who could' (§ 183).

\section{Household Strategy Five: Reliance on Consumer Debt}

Households in cluster five rely primarily on regular income (wages and pension) and consumer debt, the latter being much more important than in other clusters. They rely little on agricultural production, social transfers, and help from family members, although their reliance on savings is above average. These households' housing expenses are high, and many of them are mortgaged. They can be found in settlements of all sizes but they are over-represented in mediumsized and large cities. On average, these households consist of 3.5 members, with the majority being of working age. Typically, one member is formally employed, and one member is unemployed or inactive. Mostly, these are households of couples with or without children. Together with households in cluster three, these are the least materially deprived households in our sample (Table 3).

We labelled the household strategy of these households, which account for $32 \%$ of all households in our sample, a Reliance on Consumer Debt. They are represented by Zdenka's case (Case Summary 5).

\section{Case Summary 5. Reliance on Consumer Debt.}

Zdenka and her husband, both in their sixties, live in a family house in a coastal city. They have two daughters in their mid-twenties who attend university in another city. The daughters are 'forced to work, prolonging their education, as we are not able to finance them normally' (§6). Zdenka does not work, although she holds a quite specific employment status, which allows her to still receive some regular income. 
Her husband is retired, and both of them take temporary seasonal jobs during the summer. They cover their expenses, courtesy of income from rent: a decade ago they started renting a part of their house to tourists over summer. Their housing expenses are very high, with monthly instalments of mortgage equalling $20-30 \%$ of their overall income. They regularly use short-term consumer debt and banking overdraft to cover their expenses, and Zdenka points out that 'for me it is out of the question, with all our needs [...] to try saving or reducing the overdraft' (§ 25). They avoid borrowing from friends and family. They occasionally have some nonfinancial exchanges of favours with neighbours, friends, and family, but this is of marginal financial relevance. Although they cannot afford some more significant investments, such as replacing a very old car, Zdenka sees their living standards as above average, referring more than once to others who live far worse. They try to reduce their electricity bills but do nothing specific to reduce expenses, except distributing seasonal income over a year. ${ }^{48}$ They do not do long-term planning, given the view that 'any future we can see is up to a year' ( $\$ 67)$. The only long-term concern they have is whether their daughters will find employment, which would be 'a solution to all our problems' (§59).

\section{Household Strategy Six: Low Monetization}

The main resource of households in cluster six is low housing costs. Most of these households do not pay for the use of their living space, and some do not pay for some utilities (rather, they use heating and water from their own sources). Households of this type do not have a single dominant source of income, but combine different unstable sources. Regular income has little or no significance. Some of them produce some food for their own consumption, some rely on financial help from family members, some on the sale of assets or the use of savings, and some earn income from occasional work. Their reliance on social transfers and consumer debt is below average. They can be found in settlements of different sizes, but slightly more frequently in small rural settlements of up to 2,000 inhabitants. These are typically smaller households, predominantly single-person and much less frequently multigenerational or of atypical structure. Also, the share of children under 15 is considerably below average compared to other clusters. Typically, more than half of household members of working age are unemployed or inactive. Finally, these are extremely materially deprived households (Table 3).

We labelled the strategy of these households, who form about a tenth of our sample, a Low Monetization. Ana's story (Case Summary 6) represents this cluster.

48 This is a characteristic of households in this cluster, that is, the reliance on savings is cyclical: the above-average income from rent over the summer is distributed throughout the year. Therefore, covering of living expenses does not represent an unsustainable draining of savings. 
Case Summary 6. Low Monetization.

Ana and her husband are approaching their sixties. They are both out of the active workforce, and their budget consists of her husband's small disability pension, agricultural income, and allowances from family. They have a daughter in her midtwenties, who lives in another city where she studies, and whom they still consider a part of their household. Their older daughter has a university degree. She married and started a family of her own, so she is no longer perceived as a household member. Ana and her husband live on a tight budget and are financially dependent on their extended family support. The company where Ana used to work was liquidated in the late nineties. After losing her job, she never searched for another one, but decided to stay home and take care of the children. A few years after Ana lost her job, the firm where her husband worked was liquidated too, though he managed to get an early disability pension on account of work-related health issues. Since then, they have received significant financial help from 'their fairy godmother' (§148), a close relative. He covers a part of their regular expenses and lends them money for some more significant expenses. He also helps with their daughter's educational expenses, which he also did for their older daughter. In return, Ana and her husband supply his family with homegrown food. In Ana's words: 'He lends us, then I feed the pigs for him, we slaughter, he takes. This is how we pay him back. Like slavery (laughter)' (\$51). They make $10-20 \%$ of their overall income by selling homegrown food. The younger daughter covers some of her study costs herself by occasional freelance work, while their older daughter also helps with the bills. Ana and her husband reduced their expenses as much as they could. They never take out any bank loans and do not use overdraft. Sometimes they ask for an informal grace period from a local grocery store and cover their purchases after a month or so. But most of the food they consume, they do not purchase but produce themselves. They own a family house but lack the money to refurbish it or introduce a central heating system, and heat only a part of their house. Most small house repairs are done 'on a friendly basis' (\$140). Nevertheless, Ana says she is completely satisfied with their life and 'wouldn't change a thing' (\$144). Her only aspirations are that her younger daughter finds a job after finishing her studies.

\section{Discussion and Conclusion}

Our study identified six strategies that Croatian households with unemployed or inactive working-age members used to cope with their difficult circumstances. Based on the characteristics of these strategies, and the main resources they utilized, we labelled them: 1) struggle for independence (occasional work, help from family, regular income, savings); 2) strenuous self-reliance (regular income, social transfers); 3) successful pooling of resources (income from agriculture, low housing costs, regular income); 4) reliance on social transfers (social transfers, low housing costs); 5) reliance on consumer debt (regular income, consumer debt); and 6) low monetization (low housing costs). Judging by the scores on the material deprivation index, the most successful strategies were strategies three 
(successful pooling of resources) and five (reliance on consumer debt), which were used by the majority of the households studied. Both are strategies in which the regular income of some household members plays an important role, while other resources mainly are an additional buffer rather than a source of coping.

With households employing strategy three (successful pooling of resources), this buffer to the regular income is possible because these types of households often own land from which they can get produce to use for their own needs or for small-scale sale on the green market. In addition, they mostly own houses in which they live, which, interviews suggest, were often inherited or built/ financed during socialist times. Thus, these households are able to keep their housing costs at a minimum or even save on utility bills. Indeed, these characteristics of strategy three, which is most prevalent in rural areas, throw into sharp relief the differences between the resources of those dwelling in houses (which, in Croatia, typically come with a garden plot) and urban dwellers living in flats, who have limited access to homegrown food and limited possibilities to use alternative cost-saving utilities (such as using wood for heating). Iva, the representative of households in cluster three, summarizes this situation quite succinctly by noting that, despite all the difficulties of her own household, it is those people 'in flats' who are in a bad situation, so it is to them they sometimes give the surplus of their home-grown food (\$ 99). Combining income from regular work and agricultural production has a long tradition in Croatia, as well as in other ex-Yugoslav countries, established during the socialist period. In that period, it was quite common for workers from rural areas (often labelled 'workers-peasants' ${ }^{\prime 9}$ ) to travel to a nearby town to work in a factory and to perform agricultural work on their own land in the afternoons and during weekends, together with other family members.

The other most successful type of households, those employing strategy five (reliance on consumer debt), can also be seen as urban counterparts to mostly rural households in cluster three. For both of them, regular income is the most important factor of successful coping, but access to agricultural produce and low-cost housing that buffer regular income for households in cluster three are not available to these mostly urban households in cluster five (indeed, their housing costs are high, and they rarely rely on agricultural production). Instead, what act as additional buffers to regular income to these households are, primarily, consumer loans, credit drafts, and overdraft. Therefore, here we have a rather fragile strategy of coping that directly depends on the continuity of some source of regular income.

When households cannot rely on any source of regular income and depend primarily on alternative resources, it becomes much more difficult to cope.

49 Ivan Perić, Radnici-seljaci u industrijskim poduzećima, Sociologija sela 3, no. 7-8 (1965), 56-66, http://hrcak.srce.hr/118230. 
Specifically, if we look at the households with the worst scores on the material deprivation index, the households utilizing strategies four (reliance on social transfers) and six (low monetization), we can see that these are the only types of households where regular income plays no role as a resource.

Another resource that deserves further discussion is help from family members. Although not as crucial for coping as regular income from wages or pensions, the relevance of this informal resource has been particularly emphasized in the interviews, where it became clear that help from family members is a safety net for many members of these vulnerable households. In this respect, an interesting finding is the differentiation that the individuals use between who belongs to their household and who does not. For example, it was quite common for family members who no longer lived in the same household to be still perceived as household members. Far from being just a matter of affective affiliations, these relations mattered in terms of family finances, as both financial and non-financial help was given to and received from such 'dislocated' members without that necessarily being defined as giving and receiving external assistance. Therefore, we believe it probable that 'help from family members not living in the same household' may have been under-reported in the household survey. As it is, in the survey such help was emphasized as an important resource only for households struggling for independence (strategy one), that is, mostly urban and small households primarily consisting of a single member or a couple without children or with only one child, often young or middle-aged. It was also found above average in the households that primarily rely on social transfers (strategy four), these being mostly large households (multigenerational or with a large number of young children) from small towns or larger rural settlements.

Household strategies two (strenuous self-reliance) and four (reliance on social transfers) also highlight some policy implications of our findings. Namely, these strategies are mostly used by large households (multigenerational or with a large number of young children), where the pensions and child allowances are an important source of income. If we consider the material deprivation index of these two types of households, these findings question both the efficiency and the real function of these transfers. This is especially true of child allowances, which are a 'poverty alleviation' of limited duration. Thereby, child allowances are losing their primary function and are becoming instrumentalised by the social assistance system. Moreover, as their levels remain low and do not follow the living standard changes, they do not decrease the poverty risk of these households.

In conclusion, the findings of our study confirm that practices that households use to ensure their coping in difficult economic circumstances are indeed diverse. Similar to other studies using the concept of 'household strategies', we have 
demonstrated that these practices include the utilization of various resources in diverse combinations, from those considered more traditional (income from regular or occasional employment or pensions, social benefits, and transfers) to those considered more alternative (domestic food production, reliance on consumer debt, help from family members), as well as resources that are often the 'remnants' of 'better times' (ownership of land/housing, savings). Our study confirms that a steady low labour market participation rate is sustained by the existence of relatively successful strategies which combine regular income from work with other income sources and/or costs reductions. Around $60 \%$ of households with at least one inactive or unemployed member belong to one of the two types of households with relatively successful strategies (three and five), whose material deprivation index score is similar to the score of households where all working-age members are employed in the formal labour market. This finding suggests that passivity in the labour market can be, for some groups, a voluntary choice, or at least an acceptable second-best option when the labour market fails to provide good incentives in terms of salary and/or job security and quality. The policy implication of this finding suggests a need for development of quality job opportunities, not any job opportunities, the latter being the dominant implicit policy orientation of Croatian policymakers.

We would also like to address Clark's criticism that strategic decision-making has no place where individuals struggle for their existence by any means available. ${ }^{50}$ While, in some circumstances, individuals might indeed have little choice as to what practices or resources are at their disposal, we believe that the diversity of these practices and the various combinations in which they are used, even by similar types of households in similar circumstances, as suggested by our rich interview data, allows the space for creativity and agency that goes beyond reducing the discussion of 'household strategies' to the discussion of 'strategic action' in its strictest sense. Instead, for the purpose of analysis and understanding of vulnerable households' income-producing and cost-reducing practices, we find Warde's distinction between strong and weak (weakly or not planned) strategies ${ }^{51}$ much more useful. Applied to our results, we consider the two most successful strategies, strategies three (successful pooling of resources) and five (reliance on consumer debt), to belong to strong or planned strategies, while households relying on other types of strategies depend more on ad hoc solutions.

Finally, although we have emphasized the importance of regular income for those households with unemployed or inactive members that we consider most successful in terms of their material deprivation index scores, in this study we have additionally shown exactly how regular income interacts with other (and which) possible resources in order to increase households' chances of coping

50 Clark, Making Ends Meet in Contemporary Russia.

51 Warde, Household Work Strategies and Forms of Labour. 
with difficult economic circumstances. Specifically, we have shown the importance of owning a garden plot or house for rural dwellers or strong reliance on 'life on credit' for urban dwellers. This provides additional complexity to the understanding of household subsistence and it is, indeed, a point that illustrates that using 'household strategy' as a concept and method of analysis is fruitful in postcommunist societies such as Croatia.

\section{CORRESPONDING AUTHOR}

Dragan Bagić Department of Sociology, Faculty of Humanities and Social Sciences, University of Zagreb, Ivana Lučića 3, 10000 Zagreb, Croatia. Email: dbagic@ffzg.hr 